\title{
STANDARDIZATION OF SERVICES AS KEY COMPONENTS OF CYCLING TOURISM DESTINATION DEVELOPMENT
}

\author{
Nataša Slavić \\ Tanja Ivek
}

https://doi.org//10.20867/tosee.06.45

\begin{abstract}
Purpose - The objective of this paper is to suggest a development scenario for cycling tourism destinations in the form of a model with identified stages, stakeholders, and activities, contingent upon regional commitment and supported by EU funding. Its purpose is to evaluate the role of service standardization in cycling tourism destination development from the stakeholder perspective.

Methodology - This paper uses the case study approach in capturing practical implications of reallife regional tourism development. The conceptual model is a result of the conducted study and analysis that included qualitative data from strategic documents, implemented actions, and onsite observations, as well as the opinions, attitudes, and suggestions of tourism development stakeholders. Proposed is a more general and widely applicable cycling tourism development model, built around service standardization as the key component.

Findings - Not all regional stakeholders (primarily service providers) demonstrate willingness to adapt to cycling tourism standardization, regardless of the simplicity of criteria for a basic (entrance) level of standardization. Interestingly, service providers that already cater to cycling tourists (or have attempted to) and have adopted some kind of service customization are more responsive to regional standardization initiative. Research results confirm the standpoint of the conceptual model that service standardization plays a key role in cycling tourism development. Contribution - This research provides more insight into the stakeholder perspective of cycling tourism development. Capturing stakeholder behaviour and attitudes towards service standardization as part of the strategic regional tourism development model offers practical and managerial implications for destination management and other (potential) actors in cycling tourism development. Research results indicate that service standardization is the key component of the destination's cycling tourism development model, influenced by top-down development planning, stakeholder-involvement, and collaborative efforts at each stage.
\end{abstract}

Keywords: cycling tourism, service standardization, cycling tourism development, cycling tourism destination, cycling tourism development model.

\section{INTRODUCTION}

The connection between cycling and tourism dates further back than the 1990s when a rising academic interest in cycling tourism was noted. There are many research papers and studies in the field of cycling tourism, and the overview suggests not only a change in research methodology, but also an expansion of more explanatory research (in comparison to descriptive) (Lamont 2014). Depending on the research variables, the definition of cycling tourism varies and seems to imply a number of cycling-related activities with links to tourism (Lamont and Buultjens 2011), coming in forms ranging 
ToSEE - Tourism in Southern and Eastern Europe, Vol. 6, pp. 673-694, 2021.

N. Slavić, T. Ivek: STANDARDIZATION OF SERVICES AS KEY COMPONENTS OF CYCLING ...

from events, self-supported rides, to popular destinations. It mostly is not dependent on particular geographical features and can therefore be developed in any region (The Path Less Peddaled 2013).

Bicycle, cycle, or cycling tourism is an increasingly present phenomenon in most European countries. The EU's support of this form of responsible tourism has been increasing through the co-financing of various projects, and the incorporation of cycling in climate mitigation, regional development, or transportation plans (European Cyclists' Federation n.d.). Today, this "soft adventure tourism" (CBI 2018) is regarded as a good path of regional tourism development due to its low negative environmental impacts and the delivery of social and economic benefits, significant foremost to underdeveloped (rural) destinations (Piket, Eijgelaar and Peeters 2013; Weston et al. 2012).

The focus of available studies and academic papers is very often on the role of cycling infrastructure (primarily routes and networks) in the development of cycling tourism in a certain destination, as well as on the economic aspects of this activity, while the standardization of services is seriously under-researched. This is the gap this paper seeks to fill by case studying a destination with a service quality standardization system already in place in the initial stage of tourism product development. Accordingly, the research question this paper strives to answer is: Is standardization of services for cycling tourists recognized as a key component of cycling tourism destination development by various stakeholders involved in cycling tourism?

Being a well-established spa and wellness destination, Krapina-Zagorje County has been committing to some other forms of tourism in recent years. Its tourism product portfolio had been diversified with Zagorje Bike and Zagorje Ride, i.e., a cycling and equestrian tourism offering. The development of cycling tourism in Zagorje has passed through distinctive stages and is the outcome of the efforts of enthusiastic people in key positions, a clear vision, and successful project applications to tenders. The strategic approach is evident in the project documentation of the regional tourist board and development agency, and the interrelatedness of different projects realized in the past eight years.

This paper comprises three sections. The Theoretical context section discusses theoretical and practical contributions on the topic of cycling tourism development. The research approach, sampling, and research limitations are explained in the Research methodology section. The Research results and discussion section presents the case studied, through some general information and the chronology of cycling tourism development. It also discusses the study's results, implications, and proposes a model of cycling tourism destination development, based on the theoretical and practical context.

\section{THEORETICAL CONTEXT}

Cycling tourism research has been changing and becoming increasingly explanatory (Lamont 2014). The noticeable increase in the number of studies can be accredited to factors ranging from rising governmental interest in cycling tourism, its favourable potential in climate change mitigation, or the potential of cycling tourism to be explored from a perspective of many disciplines (Lamont 2014). The lack of a single cycling 
ToSEE - Tourism in Southern and Eastern Europe, Vol. 6, pp. 673-694, 2021.

N. Slavić, T. Ivek: STANDARDIZATION OF SERVICES AS KEY COMPONENTS OF CYCLING ...

tourism definition is not necessarily considered as being negative. It has rather been the outcome of constructing definitions based on the specific circumstances of a study or an area that is being explored - resulting in different typologies of cycling tourists (e.g., European Parliament 2009; Lamont 2009; Lamont and Buultjens 2011; Lamont and Jenkins 2013; Marcussen 2009; Mintel 2009; Ritchie et al. 2010; Sustrans 1999; Weed et al. 2014), the lack of comparable data sets, and the lack of a unified systematic approach in capturing the volume and the value of cycling tourism.

\subsection{Cycling tourism destination development}

Cycling tourism is often domestic (ADFC 2017; The Outdoor Industry Association 2018), but aside from its contribution to local catering, retail and services sectors (Fahrradportal 2017), it also has a broader impact (Adventure Cycling Association n.d.; The Outdoor Industry Association 2018). Cycling tourism development is found to be economically (e.g., Buning and McNamee 2016; Kaya and Erdoğan 2020; Preez and Lee 2016), socially, and environmentally beneficial in natural, often remote areas in the long run (Gazzola et al. 2018). It also has the potential to help local economies recover from natural disasters (Di Giacobe, Di Ludovico and D'Ovidio Corrected Proof) and the effects of mass tourism, capacity constraints, and/or high seasonality (Lörincz, Banász and Csapó 2020). A coherent development of cycling tourism therefore requires clear guidelines and monitoring (Institute for Transport Studies, University of Natural Resources and Life Sciences 2019).

The difficult process of attracting public funding and authorities' support for recreational and leisure cycling infrastructure could be relieved by quantitative methodological tools for cycling-tourism networks design (Giovannini, Malucelli and Nonato 2017). Publicly funding infrastructure and cycling support services, accompanied by strong marketing, translates into stronger cycling tourism development (Mintel 2009). However, the bottom-up approach, supported by community initiatives and bicycle commuting (the basis of the cycling tourism destination development pyramid according to Krieger (2007), seems to yield in favour of the top-down approach, which is simultaneously able to appeal to cycling tourists and local demand (Chang and Chang 2003).

While physical infrastructure plays a central role (Kaya and Erdoğan 2020), regional cycling tourism development is also affected by natural attractions, stakeholder collaboration, bicycle-friendly tourist services, as well as by promotion and marketing efforts (Çelik Uğuz et al. 2019), land-use systems, landowner cooperation, and governmental support (Pratte 2006). Strategies and activities that popularize the bicycle, such as designing mobile apps for cycling tourists, making infrastructural upgrades, and developing tours to important heritage sites (Soyalp 2018) help boost regional cycling.

The aforementioned determinants of cycling tourism destination development in the relevant academic papers and studies on the matter are grouped into four categories as presented in Figure 1. 
ToSEE - Tourism in Southern and Eastern Europe, Vol. 6, pp. 673-694, 2021.

Figure 1: The determinants of cycling tourism destination development according to academic research

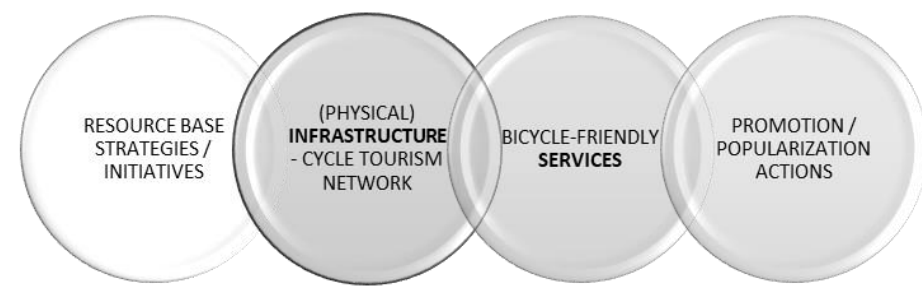

Source: Authors' own construction, based on the analysis of academic sources listed in this section

The Resource base category implies all comparative resources, primarily natural and cultural. It also includes strategic documents, that can easily achieve the set objectives if accompanied by social initiatives, stakeholder cooperation, government support, publicprivate cooperation, and clear guidelines and monitoring. Infrastructure has a central role in the cycling tourism offering but often lacks networking which would support its wider use and benefits. Bicycle-friendly services act as the superstructure of the cycling tourism offering and add value to cycling in a region, whether in the form of general tourist services adapted to cyclists' needs or in the form of sport-specific services (such as bicycle repair shops). Strong promotion of cycling has internal marketing at its core, while the social visibility of local bicycle use supports the image of a cycling destination, valued by some types of tourists.

\subsection{Cycling tourism service standardization schemes}

Cycling tourism development is supported by international and national service standardization schemes, some of which were initiated by for-profit accommodation service provider affiliations, and others by (tourism) authorities. Hotel affiliations such MountainBike Holidays and RoadBike Holidays, are based on customized services (MountainBikeHolidays 2021; RoadbikeHolidays 2021), 3-level internal service standardization systems, clear market orientation, and quality control guarantee (MountainBikeHolidays 2021). In addition, these and similar affiliations offer cyclists "plus" services (RoadbikeHolidays 2021), targeting their specific demands. The regional offering is inextricably linked to their services.

Differing from the above affiliations in the extent of service standardization, membership requirements, and strategy are the ADFC's (Allgemeine Deutsche Fahrrad-Club) Bett+Bike cycling tourism service standardization initiative with two defined levels of cyclists friendly hospitality services criteria (Bett+Bike ADFC 2021), and the international Cyclists welcome network (Cyclists Welcome 2018), whose standards are applied to cyclist-friendly accommodation and catering service providers, as well as to entire destinations (Cykliste vitani n.d.). In addition, CW also promotes cities, regions, and bicycle routes through itineraries, thematic tours, testimonials, and storytelling. 
ToSEE - Tourism in Southern and Eastern Europe, Vol. 6, pp. 673-694, 2021.

N. Slavić, T. Ivek: STANDARDIZATION OF SERVICES AS KEY COMPONENTS OF CYCLING ...

Unlike for-profit affiliations, regionally adopted service standardization systems are much simpler in terms of market segmentation and criteria elaboration (the number of standards and quality levels implemented), planned as part of the entire destination's strategic management and aimed at involving a variety of stakeholders (local population, local businesses, NGOs, cycling clubs, etc.) in the development process. The analysis confirms that while many models are similar, no two cycling tourism destination development models are the same. For example, the Slovenian service standardization Kolesarski trženjski standardi (Združenje za pohodništvo in kolesarjenje giz 2017) has five levels of overly elaborate standardization criteria for cycling tourism facilities, while the criteria pertaining to destinations, routes and agencies are not so finely developed (Združenje pohodništvo in kolesarjenje giz 2018; Rotar 2012; Skupnost občin Slovenije: Priročnik za razvoj kolesarskih destinacij 2016). In contrast, the regulation in Croatia (the special standard "BIKE"; Croatian Ministry of Tourism 2016, Official Gazette $56 / 2016$, art. 46) is somewhat vague and does not incorporate practical achievements.

The regional "Istrian model" (Istra Bike n.d.) of complementary infrastructure network, accommodation standardization, and constant promotion (events, and information availability) has become good know-how for regions like Split-Dalmatia (Turistička zajednica Splitsko-dalmatinske županije; Biciklistički savez Splitsko-dalmatinske županije; Splitsko-dalmatinska županija 2015), while others apply Cyclist Welcome Quality (CWQ) standards for accommodation, catering, and tourist information facilities (Međimurje Bike n.d.), as well as for the destination, rent-a-bike and travel agencies (RAM DC d.o.o. Čakovec for Zagreb County tourism board 2017) ${ }^{1}$.

Building on the basic composition of cycling tourism supply (Figure 1), Figure 2 incorporates additional elements and implies a more elaborate structure in line with the practical achievements in cycling tourism (service) development and the variety of modes present in communicating with the market. The difference (compared with Figure 1 ) is in the focus on upgrading the infrastructure through networking and adding other infrastructural elements, such as rest stops equipped to cater to cyclists needs while cycling. Also, examples from practice underline the need of service standardization in order to be able to control and guarantee a certain level of quality.

\footnotetext{
${ }^{1}$ Since 2017, the Croatian Ministry of Tourism has been co-financings the development of cycling tourism through programmes of Cycling Tourism Development (Ministarstvo turizma i sporta 2021) and Public Tourism Infrastructure Development (Europski fondovi 2019), which is why all continental and several coastal counties have operational plans for cycling tourism development. Unfortunately, the implementation of such plans is sometimes lacking and there is no unified website that would allow tourists to get information on the networked cycling routes in one place.
} 
ToSEE - Tourism in Southern and Eastern Europe, Vol. 6, pp. 673-694, 2021.

Figure 2: The determinants of cycling tourism destination development according to practical achievements

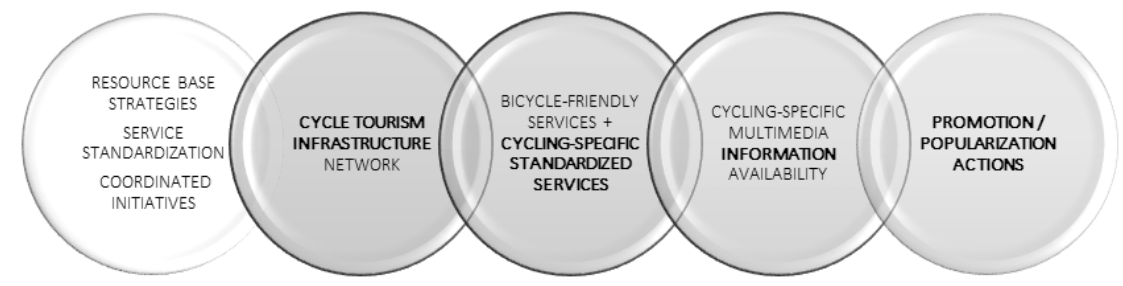

Source: Author's own construction, based on the analysis of available real-life examples listed in this section

Service standardization is founded in the strategic base of development, but a key component of cycling-specific services category. Information availability refers to specific activity-related information in a number of forms that are important for activityinvolvement and cycling in the destination (GPS downloadable data, itineraries, digital maps, thematic portfolios, etc.) and therefore extracted from Promotion actions. A huge part of the promotional activities of cycling tourism regions are actually events of all types, although in a substantially smaller share given the COVID-19 pandemic circumstances.

Relative to the presented determinants of cycling tourism supply, the destination area management's (i.e., the regional tourism authority's) functions, actions, and activities in cycling tourism development are found to include the following:

- having a clear vision, based on comparative advantages of a destination, profiling a destination's market approach;

- creating an infrastructural base for cycling, route planning, creating a network and constantly upgrading infrastructure and facilities, adding thematic elements and itineraries;

- creating an integrated destination product - integrating the available resource base, and natural and cultural heritage into the cycling tourism offering, but also integrating cycling tourism into a more elaborate (outdoor) offering of an area; enabling cyclingspecific additional services;

- communicating with demand (information-availability, updating, real-time info, available downloads, multi-media contents) through websites, social networks, specialized platforms, and mobile apps;

- promoting the destination (through tourist fairs, media, targeting special-interest tourists, cycling event organization or support, thematic offering) based on quality guarantee enabled by a service standardization system and stakeholder capacity building; also requires internal promotion and popularizing cycling among the local population (promotional events);

- ensuring stakeholder involvement, collaboration, public/private/governmental support, and supporting community initiatives;

- boosting stakeholder capacities through training/education;

- ensuring the quality of all services involved in cycling tourism supply - service standardization procedures, criteria, and implementation;

- profiling supply, branding a destination (also) as a cycling destination. 
ToSEE - Tourism in Southern and Eastern Europe, Vol. 6, pp. 673-694, 2021.

N. Slavić, T. Ivek: STANDARDIZATION OF SERVICES AS KEY COMPONENTS OF CYCLING ...

The determinants in Figures 1 and 2, as well as the list of destination management functions, actions, and activities were incorporated into the questionnaire used to survey the stakeholders of cycling tourism development in the studied case.

\section{RESEARCH METHODOLOGY}

This paper uses the case study approach to capture a real-life example of regional cycling tourism development (Krapina-Zagorje County). The conceptual model proposed in this paper is the result of a comprehensive approach to studying the cycling tourism destination development.

\subsection{Research design and realization}

Expert sampling was used to gather attitudes from cycling tourism development stakeholders in the studied destination area. Lists of 357 participants previously involved in different activities in cycling tourism development, provided by a regional tourism organization and a regional development agency, served as a framework for sample selection and enabled identifying informants considered well-informed about the problems, successful and less successful initiatives, and expected development trends (Patton 2018) in cycling tourism, with the help of a formal list of questions (Juneja n.d.). Of the 68 experts chosen for the survey based on the criteria of activity-involvement, occupation, and residing in the area, the sample involved 28 experts willing to provide their judgement, resulting in $41.18 \%$ response rate.

The opinions and attitudes from people considered as being the most knowledgeable, and best informed, or having the most experience in the topic/area (Marušić, Prebežac and Mikulić 2019) of cycling tourism were gathered through online self-completion surveys (instead of interviews) due to the Covid-19 circumstances, but also because of the general advantages of such an approach and the fact that the research design called for purposive sampling and the contact information of the targeted individuals was known to the authors. The survey method was used due to its potential in collecting primary data and capturing the attitudes of people, and for its wide applicability in both quantitative and qualitative studies, and because by using this method it is possible "to uncover quantitative and qualitative features in the present, to a good extent in the past, and partially in the future" (Marušić, Prebežac and Mikulić 2019, 187).

The design of the questionnaire was informed by qualitative research of cycling tourism development documents (primarily the Ride\&Bike standardization rulebook (Faculty of Tourism and Hospitality Management 2019)), analysed in the initial stage of research, as required (Queensland Government Statistician's Office 2019). The questionnaire was distributed to the selected group of experts in March 2021 through an e-mail by the regional development agency, containing the purpose and the objective of this research, as well as a link to an online form that was available for 15 days. It was previously pilottested on a small-scale, and modified according to some design shortcomings. It contained mostly structured questions. 
ToSEE - Tourism in Southern and Eastern Europe, Vol. 6, pp. 673-694, 2021.

N. Slavić, T. Ivek: STANDARDIZATION OF SERVICES AS KEY COMPONENTS OF CYCLING ...

\subsection{Research limitations}

While online self-completion surveys have many advantages, there are also potential issues researchers need to anticipate, such as the potential low return rate, lack of control over the environment in which the examination takes place, the inability to provide additional explanations, anonymity, etc. A relatively small and purposive sample could be considered as one of the study's limitations. However, when the purpose of the research is to gather information from experts, this serves as a justification for deliberately selecting a smaller number of respondents, who are more involved in the research subject and know more about the subject than the average respondent. A purposive sample is justified in research in which the purpose is not to draw conclusions about the size of the studied phenomenon, but about its nature (Marušić, Prebežac and Mikulić 2019, 138).

The Covid-19 pandemic has changed tourism reality and could possibly influence the respondents' judgement, particularly with regard to the future. Although it also resulted in modifying the survey method execution from interviews to online questionnaires, the authors tried to minimize the effects on the scope of the research through sample selection - focusing on more experienced stakeholders.

\section{RESEARCH RESULTS AND DISCUSSION}

In line with the paper's purpose, research question, and approach, the Krapina-Zagorje County cycling tourism offering was evaluated by its stakeholders, whose judgements are discussed in this section.

\subsection{Krapina-Zagorje County - designing a cycling tourism destination}

Krapina-Zagorje County is situated in the northwest part of Croatia, close to the Croatian capital. The county covers an area of $1,224 \mathrm{~km}^{2}$, administratively divided into seven towns and 25 municipalities, with 132,892 inhabitants (The Croatian Bureau of Statistics 2011). In Croatia, it borders on Varaždin County, the City of Zagreb, and Zagreb County, and shares an international border with the Republic of Slovenia. The area which is today administratively defined as Krapina-Zagorje County is a synonym for picturesque hills and valleys, mineral and thermal springs and a modern spa and wellness offering, castles and medieval fortresses, and other remnants of ancient times. Rich in natural resources, the stage for major events in Croatian history and the home of important individuals who played vital roles in the political and cultural life of Croatia, this region is also the largest Croatian pilgrimage destination. All this makes Zagorje a region capable of offering a variety of experiences (Tourist Board of Krapina - Zagorje county 2021).

In addition to the innovative additions to its tourism offering, such as The Tree Top Walk in Zelenjak, a helicopter flight simulator in Heli centar Toplice, and The Science Park, Zagorje continuously seeks to broaden the range of its attractions. While the region's geographical diversity makes it appealing to outdoor sport enthusiasts, its humid continental climate tends to limit outdoor activity. Cycling infrastructure in the region 
ToSEE - Tourism in Southern and Eastern Europe, Vol. 6, pp. 673-694, 2021.

N. Slavić, T. Ivek: STANDARDIZATION OF SERVICES AS KEY COMPONENTS OF CYCLING ...

caters to a variety of potential users, offering gravel, road, mountain bike and family routes, as well as local, county and cross-county routes (Zagorje Bike: Experience Zagorje in a special way 2021). Zagorje strategically addressed cycling tourism in 2013 when the first project "Network of Krapina-Zagorje County Cycling Tourist Routes" was delivered in an overall attempt to build a regional cyclist destination, with the financial support of the Croatian National Tourist Board. The County marked, digitalized and GPS-tracked cyclist routes, and designed cycling maps and a cycling-specific website (Table 1). The main goal was to promote the regional landmarks to cycling tourists.

The second project, "Development of selective forms of tourism in the cross-border tourist destination - RIDE\&BIKE", was co-financed through the European Regional Development Fund. The project aimed at strengthening cross-border destination identity and designing new cross-border tourism products with emphasis on cycling. It involved tourism authorities, regional development agencies, and public institutions from Croatia and Slovenia, led by the Zagorje Development Agency. A substantial contribution was made to the Krapina-Zagorje cycling tourism offering (see Table 1, “outputs").

\section{Table 1: Cycling tourism development in Krapina-Zagorje County}

\begin{tabular}{|c|c|c|}
\hline Development stage & Objectives & Outputs (cycling tourism offering) \\
\hline $\begin{array}{c}\text { Network of Krapina- } \\
\text { Zagorje County cycling } \\
\text { tourist routes (2013-2015) }\end{array}$ & $\begin{array}{l}\text { - designing a network of cycling } \\
\text { routes - integrating the existing } \\
\text { infrastructure (preferring scenic } \\
\text { to road trails) } \\
\text { - integrating cultural, historical } \\
\text { and natural features of the entire } \\
\text { Zagorje area into newly created } \\
\text { cycling routes } \\
\text { - upgrading quality and out-of- } \\
\text { season tourism offering } \\
\text { - promoting healthy lifestyle and } \\
\text { environmental protection } \\
\text { - designing cycling itineraries }\end{array}$ & $\begin{array}{l}\text { - a network of cycling routes } \\
\text { adapted to the widest range of } \\
\text { users, connecting the most } \\
\text { important sites in the area - } 21 \\
\text { cycling routes }(688 \mathrm{~km}) \\
\text { - online information / promotion - } \\
\text { designated web ZagorjeBike } \\
\text { (www.zagorjebike.com.hr) } \\
\text { - electronic and printed material on } \\
\text { the cycling route network, } \\
\text { including } 4 \text { cycling maps } \\
\text { - Geo-Database of cycling routes }\end{array}$ \\
\hline $\begin{array}{c}\text { Development of selective } \\
\text { forms of tourism in the } \\
\text { cross-border tourist } \\
\text { destination - RIDE\&BIKE } \\
\text { (2015-2016) } \\
\text { Participating regional } \\
\text { stakeholders: Zagorje } \\
\text { Development Agency, } \\
\text { Tourist Board of Krapina- } \\
\text { Zagorje County } \\
\text { Project value: } 395.746,60 €\end{array}$ & $\begin{array}{l}\text { - } \text { strengthening cross-border } \\
\text { destination identity } \\
\text { - integrating rural tourism and } \\
\text { specific forms of tourism } \\
\text { - enhancing tourism infrastructure } \\
\text { and facilities } \\
\text { - strengthening cooperation } \\
\text { between tourism suppliers } \\
\text { - preservation of cultural and } \\
\text { natural heritage } \\
\text { - improving the quality of life } \\
\text { - increasing the awareness of } \\
\text { sustainable tourism }\end{array}$ & $\begin{array}{l}\text { - } 2 \text { new cycling routes marked and } \\
\text { integrated in a cross-border route } \\
\text { - the first specialized cycling } \\
\text { guide training; specific training } \\
\text { for tour guides } \\
\text { - } 5 \text { cycling rest stops implemented } \\
\text { - upgraded cycling website } \\
\text { - designed promotional material } \\
\text { and presentation at specialized } \\
\text { tourist fairs } \\
\text { - smartphone cycling application } \\
\text { - designed pilot for public bike } \\
\text { share system }\end{array}$ \\
\hline
\end{tabular}


ToSEE - Tourism in Southern and Eastern Europe, Vol. 6, pp. 673-694, 2021.

N. Slavić, T. Ivek: STANDARDIZATION OF SERVICES AS KEY COMPONENTS OF CYCLING ...

Table 1 (continued)

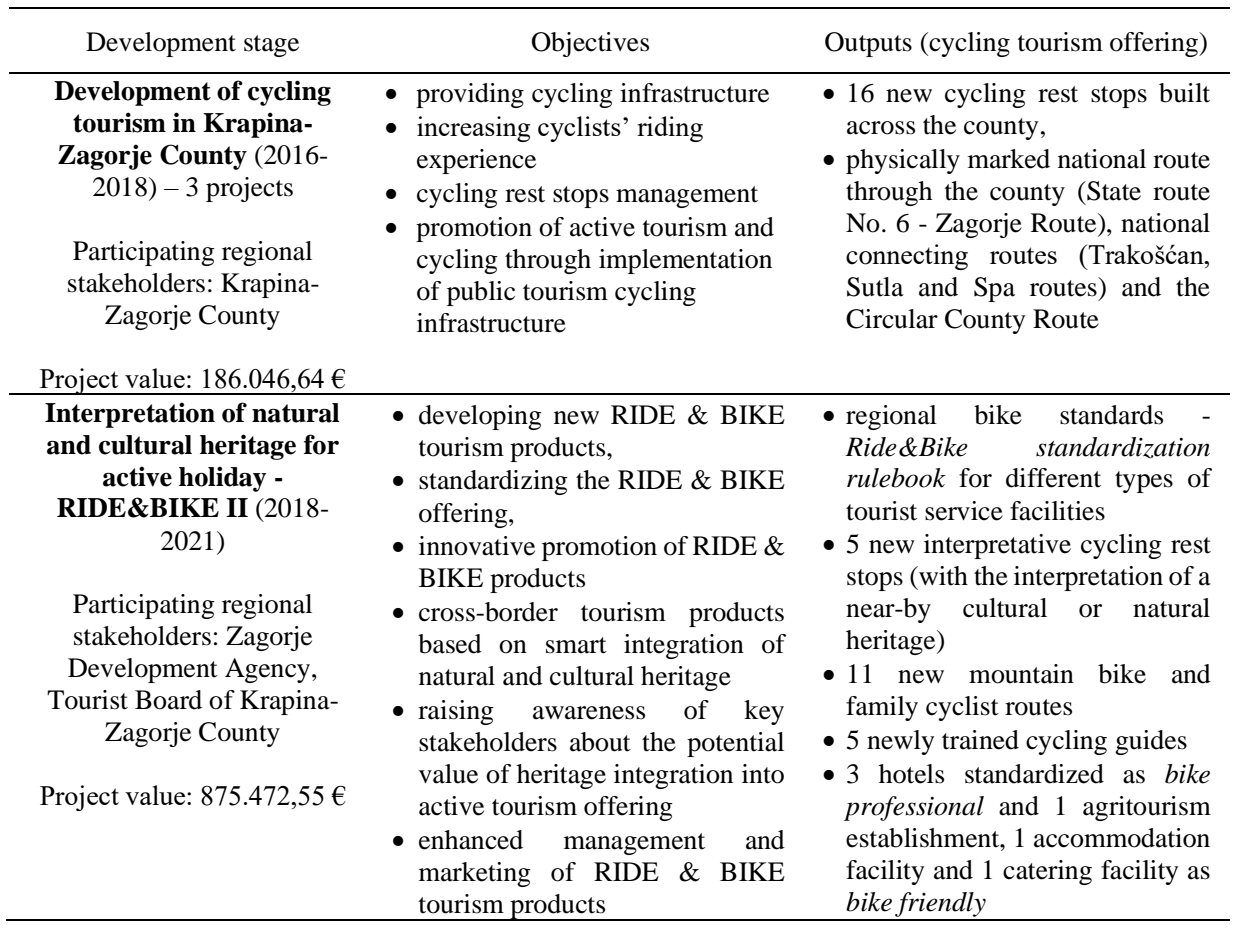

Source: Authors' own construction; regional EU projects' documentation (internal); Ride\&Bike: Ride\&Bike info 2021; Zagorje Bike n.d.

In addition to EU projects, Krapina-Zagorje County also implemented three smallerscale projects to improve cycling infrastructure, subsequent to the Ride\&Bike project (Table 1).

The project "Interpretation of natural and cultural heritage for active holiday RIDE\&BIKE II" (Zagorska razvojna agencija 2017) was an important step forward in cycling destination management in line with the integration of the natural and cultural heritage into the tourism offering aimed at activity-focused tourists whose main interest was not the natural/cultural offering during their cycling vacations/visits. Based on EU funding (European Regional Development Fund, Interreg V-a), this was the most significant and comprehensive phase of development of both the entire cross-border cycling tourism destination and the individual regions. With this project, KrapinaZagorje County adopted new key cycling tourism developments (see Table 1, "outputs"), the most significant being the standardization of the offering, the labelling of facilities as bike friendly, bike professional or bike specialist, and the implementation of the procedures and criteria set by the Ride\&Bike standardization rulebook.

Cycling tourism development requires a lot of time, strategic commitment, and investments - regional, national and EU funds. An overview of the investments made in 
ToSEE - Tourism in Southern and Eastern Europe, Vol. 6, pp. 673-694, 2021.

N. Slavić, T. Ivek: STANDARDIZATION OF SERVICES AS KEY COMPONENTS OF CYCLING ...

cycling infrastructure in Zagorje (Chart 1) provides insight into the changes that have taken place in the last 8 years.

Chart 1: Investments (€) in cycling infrastructure in Krapina-Zagorje 2012-2021

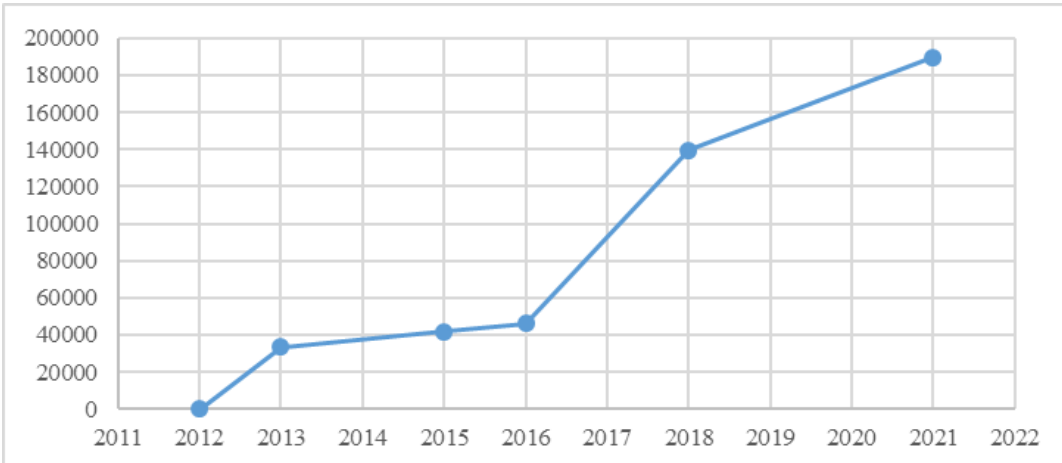

Source: Authors' own construction, based on internal project documentation

The region, which previously had no cycling tradition or cycling culture, succeeded in influencing changes in lifestyle (with growing numbers of locals engaging in cycling), and encouraging residents' involvement in infrastructure use and maintenance and their positive attitude towards cycling tourism. The region has also built a substantial cycling infrastructure (approx. 40 routes for different-ability cyclists with well-equipped rest stops), developed guided and self-guided tour options, provided education for cycling guides, and enabled constant information-availability (including recommendations and inspiration) for cycling in the region. All of the above-mentioned projects have incorporated promotional activities (leaflets, posters, maps, fair exhibitions, online and offline advertisements), contributing to the visibility of Zagorje as a cycling tourism destination. Public investments have encouraged private stakeholder involvement in, and funding of, the cycling tourism offering and services complementary to cycling. As a result, Krapina-Zagorje County is prepared to further invest to ensure its integrated and complete development as a cycling tourism destination. Future plans include the construction of specialized facilities such as the "pump track" in Donja Stubica and the comprehensive branding of the County's entire outdoor offering.

\subsection{Stakeholder perspective on cycling tourism in Krapina-Zagorje County}

The sampling criteria resulted in an expert sample structure deemed appropriate for this research. The sample is made of accommodation service sector representatives (36\%), followed by destination management $(18 \%)$, outdoor sports and recreational service providers $(14 \%)$, and other tourism service providers (in total $32 \%$ ) that directly or indirectly affect the regional offering.

In addition to accommodation sector stakeholders in the sample, several other experts (primarily representatives of destination management and outdoor sports) also provide accommodation services, making a total of $46 \%$ of respondents. Around half of the 
ToSEE - Tourism in Southern and Eastern Europe, Vol. 6, pp. 673-694, 2021.

N. Slavić, T. Ivek: STANDARDIZATION OF SERVICES AS KEY COMPONENTS OF CYCLING ...

surveyed accommodation providers offer facilities adapted for cycling tourists, but only 1 in 5 is actually standardized according to the Ride\&Bike standardization rulebook of Krapina-Zagorje (Faculty of Tourism and Hospitality Management 2019). Around two thirds of the accommodation providers $(66.67 \%)$ who are already experienced in hosting cyclists, express satisfaction with this type of guests.

As said, the questionnaire was informed by the qualitative assessment of the existing documents that shape cycling tourism development in the studied region and the examples of approaches to cycling tourism found on the market. The cross-section of cycling tourism supply elements from academic sources (Figure 1), and the practicebased achievements (Figure 2), resulted in grouping the identified cycling tourism supply elements into several categories (i.e., survey sections): 1 . cycling tourism infrastructure and supporting facilities; 2 . tourism and catering services for cycling tourists; 3 . events for cyclists; and 4. destination management functions, actions and activities.

With survey questions being structured, the emphasis was on capturing attitudes about the importance of and satisfaction with the individual elements of cycling tourism supply. The results in Tables 2 to 5 demonstrate the stakeholders' evaluation of 39 individual statements representing the elements of cycling tourism offering. A 5-point Likert scale was applied in measuring importance and satisfaction as it allows the obtained answers to be treated as interval scales on the basis of numerical values which encode the obtained answers (Marušić, Prebežac i Mikulić 2019, 201). Importance was evaluated in the range from 1 to 5 , where 1 implies "extremely unimportant", and 5 "extremely important". Satisfaction was also assessed on a scale from 1 to 5 , with 1 meaning "extremely dissatisfied", and 5 "extremely satisfied".

Table 2: Stakeholder attitudes towards the elements of Cycling tourism infrastructure and supporting facilities, ranked according to importance

\begin{tabular}{lcccc}
\hline $\begin{array}{l}\text { Cycling tourism infrastructure and } \\
\text { supporting facilities }\end{array}$ & $\begin{array}{c}\text { A.M. } \\
\text { importance }\end{array}$ & $\begin{array}{c}\text { STD } \\
\text { importance }\end{array}$ & $\begin{array}{c}\text { A.M. } \\
\text { satisfaction }\end{array}$ & $\begin{array}{c}\text { STD } \\
\text { satisfaction }\end{array}$ \\
\hline Specialized regional cycling website & $\mathbf{4 . 8 2}$ & 0.48 & $\mathbf{2 . 9 6}$ & 1.26 \\
Online maps of cycling infrastructure & $\mathbf{4 . 6 8}$ & 0.55 & $\mathbf{2 . 7 9}$ & 1.13 \\
Bicycle routes - physically marked & $\mathbf{4 . 6 4}$ & 0.62 & $\mathbf{2 . 6 4}$ & 1.10 \\
Network of cycling infrastructure & $\mathbf{4 . 6 1}$ & 0.69 & $\mathbf{2 . 7 1}$ & 1.24 \\
Bike routes for a wide range of recreational & $\mathbf{4 . 5 7}$ & 0.57 & $\mathbf{2 . 7 1}$ & 1.27 \\
cyclists & $\mathbf{4 . 5 7}$ & 0.63 & $\mathbf{2 . 7 1}$ & 1.21 \\
Bike routes for families with children & $\mathbf{4 . 5 4}$ & 0.69 & $\mathbf{2 . 8 9}$ & 1.23 \\
Online (downloadable) bike routes & $\mathbf{4 . 4 6}$ & 0.74 & $\mathbf{2 . 8 2}$ & 1.44 \\
Equipped bicycle rest stops & $\mathbf{4 . 2 1}$ & 0.83 & $\mathbf{2 . 6 1}$ & 1.17 \\
Cross-border, international and / or & $\mathbf{4 . 1 8}$ & 0.77 & $\mathbf{2 . 4 6}$ & 1.17 \\
transnational bicycle routes & $\mathbf{4 . 1 1}$ & 0.83 & $\mathbf{2 . 1 4}$ & 1.24 \\
Bike routes / trails for professional cyclists & $\mathbf{3 . 7 9}$ & 0.96 & $\mathbf{2 . 8 6}$ & 1.33 \\
Bike parks & $\mathbf{4 . 4 3}$ & 0.70 & $\mathbf{2 . 6 9}$ & 1.23 \\
Printed maps of cycling infrastructure & & & & \\
Overall & &
\end{tabular}

Source: Authors' own construction 
ToSEE - Tourism in Southern and Eastern Europe, Vol. 6, pp. 673-694, 2021.

N. Slavić, T. Ivek: STANDARDIZATION OF SERVICES AS KEY COMPONENTS OF CYCLING ...

Information that enables activity and involvement (specialized website, and online maps) is perceived as the most important aspect in this category. The importance of physical infrastructure in the cycling tourism offering is also confirmed by the experts' evaluation, with the highest score given to signposted bicycle routes and infrastructure networking, followed by the availability of cycling infrastructure suited for recreational cyclists and families with children. The respondents are the least unanimous in their opinion of the importance of printed maps (STD importance), which is also the least important element of this category. However, according to the level of stakeholders' satisfaction, this element is ranked third among the offering elements, coming after the specialized cycling tourism website and downloadable bike routes.

Table 3: Stakeholder attitudes toward the elements of the Tourism and catering services for cycling tourists category, ranked according to importance

\begin{tabular}{lcccc}
\hline $\begin{array}{l}\text { Tourism and catering services for cycling } \\
\text { tourists }\end{array}$ & $\begin{array}{c}\text { A.M. } \\
\text { importance }\end{array}$ & $\begin{array}{c}\text { STD } \\
\text { importance }\end{array}$ & $\begin{array}{c}\text { A.M. } \\
\text { satisfaction }\end{array}$ & $\begin{array}{c}\text { STD } \\
\text { satisfaction }\end{array}$ \\
\hline $\begin{array}{l}\text { Bicycle rental services } \\
\text { "Package tours" for cycling tourists }\end{array}$ & $\mathbf{4 . 6 8}$ & 0.61 & $\mathbf{2 . 6 1}$ & 1.17 \\
$\begin{array}{l}\text { Thematic (guided) tours for cyclists } \\
\text { Catering facilities along bike routes }\end{array}$ & $\mathbf{4 . 4 6}$ & 0.74 & $\mathbf{2 . 4 3}$ & 1.17 \\
$\begin{array}{l}\text { Accommodation facilities, affiliated to bike } \\
\text { service standardization system }\end{array}$ & $\mathbf{4 . 4 6}$ & 0.79 & $\mathbf{2 . 6 1}$ & 1.26 \\
$\begin{array}{l}\text { Standardized "bike-friendly" catering } \\
\text { facilities }\end{array}$ & $\mathbf{4 . 4 3}$ & 0.78 & $\mathbf{2 . 7 1}$ & 1.27 \\
$\begin{array}{l}\text { Cycling tourism service standardization } \\
\text { system (regulation, procedures, labelling) }\end{array}$ & $\mathbf{4 . 4 2}$ & 0.73 & $\mathbf{2 . 4 3}$ & 1.10 \\
$\begin{array}{l}\text { Bicycle repair shops } \\
\text { Certified local bicycle guides }\end{array}$ & $\mathbf{4 . 3 6}$ & 0.77 & $\mathbf{2 . 4 3}$ & 1.10 \\
$\begin{array}{l}\text { Thematic (self-guided) bike tours online - } \\
\text { available for download }\end{array}$ & $\mathbf{4 . 3 6}$ & 0.77 & $\mathbf{2 . 6 4}$ & 1.19 \\
$\begin{array}{l}\text { Standardized "bike-friendly" cultural and } \\
\text { natural heritage sites along bike routes }\end{array}$ & $\mathbf{4 . 3 6}$ & 0.73 & $\mathbf{2 . 7 1}$ & 1.30 \\
$\begin{array}{l}\text { Bicycle (equipment) shops } \\
\text { Overall }\end{array}$ & $\mathbf{4 . 2 8}$ & 0.84 & $\mathbf{2 . 5 0}$ & 1.23 \\
\hline
\end{tabular}

Source: Authors' own construction

Relative to the available studies which demonstrate the economic potential of cyclingspecific and bicycle-friendly services for local economy, the overall score regarding the importance of services for cycling tourists (in comparison to other categories) indicates a potential lack of information about and awareness of the potential benefits of cycling tourism among stakeholders and could be the reasoning behind the currently perceived importance of individual service standardization aspects. Although mostly ranked among the top five in this category, they are rated as being less important than some more massfocused services. The experts expressed the most satisfaction with (non-standardized) catering facilities along routes and with local cycling guides. 
ToSEE - Tourism in Southern and Eastern Europe, Vol. 6, pp. 673-694, 2021.

N. Slavić, T. Ivek: STANDARDIZATION OF SERVICES AS KEY COMPONENTS OF CYCLING ...

Table 4: Stakeholder attitudes towards the elements of the Events for cyclists category, ranked according to importance

\begin{tabular}{lcccc}
\hline Events for cyclists* & $\begin{array}{c}\text { A.M. } \\
\text { importance }\end{array}$ & $\begin{array}{c}\text { STD } \\
\text { importance }\end{array}$ & $\begin{array}{c}\text { A.M. } \\
\text { satisfaction }\end{array}$ & $\begin{array}{c}\text { STD } \\
\text { satisfaction }\end{array}$ \\
\hline Promotional cycling events in the area & $\mathbf{4 . 4 6}$ & 0.69 & $\mathbf{2 . 6 8}$ & 1.09 \\
Year-round offering of cycling events & $\mathbf{4 . 4 3}$ & 0.69 & $\mathbf{2 . 4 3}$ & 1.10 \\
Integration of cycling events with the local & $\mathbf{4 . 3 9}$ & 0.88 & $\mathbf{2 . 6 1}$ & 1.10 \\
cultural or natural heritage & $\mathbf{4 . 3 6}$ & 0.73 & $\mathbf{2 . 4 6}$ & 1.00 \\
Bicycle competitions organized in the area & $\mathbf{4 . 4 1}$ & 0.75 & $\mathbf{2 . 5 5}$ & 1.07 \\
Overall & & & & \\
\hline
\end{tabular}

* The events are extracted in a separate category as a specific segment of the offering, aimed at attracting visitors to the destination, in which destination management does not necessarily have an organizational role.

Source: Authors' own construction

All items, in the "cycling events" category, were rated with scores mostly higher than 4 ("important"), with competitive sports events receiving the lowest score. According to the stakeholders' opinions, the destination's offering should focus on promotional cycling events and a year-round programme featuring a variety of events for cyclists and cycling tourists. The score given by stakeholders to express their level of satisfaction suggest that the greatest focus in the destination is currently placed on promotional cycling events and their integration into the local resource base (natural and cultural).

Table 5: Stakeholder attitudes towards the elements of the Destination management functions, actions and activities category, ranked according to importance

\begin{tabular}{lcccc}
\hline $\begin{array}{l}\text { Destination management functions, actions } \\
\text { and activities }\end{array}$ & $\begin{array}{c}\text { A.M. } \\
\text { importance }\end{array}$ & $\begin{array}{c}\text { STD } \\
\text { importance }\end{array}$ & $\begin{array}{c}\text { A.M. } \\
\text { satisfaction }\end{array}$ & $\begin{array}{c}\text { STD } \\
\text { satisfaction }\end{array}$ \\
\hline $\begin{array}{l}\text { Promotion of cycling tourism at tourist fairs } \\
\text { and in the media }\end{array}$ & $\mathbf{4 . 7 1}$ & 0.53 & $\mathbf{2 . 5 0}$ & 1.20 \\
$\begin{array}{l}\text { Education/trainings for cycling guides } \\
\begin{array}{l}\text { Sustainable use of natural resources through } \\
\text { the cycling tourism offering }\end{array}\end{array}$ & $\mathbf{4 . 6 1}$ & 0.63 & $\mathbf{2 . 7 1}$ & 1.21 \\
$\begin{array}{l}\text { Education/trainings for cycling tourism } \\
\text { service providers }\end{array}$ & $\mathbf{4 . 5 7}$ & 0.63 & $\mathbf{2 . 4 6}$ & 1.04 \\
$\begin{array}{l}\text { Publicly available (seasonal) programmes } \\
\text { with all cycling services }\end{array}$ & $\mathbf{4 . 5 7}$ & 0.63 & $\mathbf{2 . 6 8}$ & 1.12 \\
$\begin{array}{l}\text { Organization of cycling events } \\
\begin{array}{l}\text { Interpretation of heritage and tradition } \\
\text { through the cycling tourism offering }\end{array}\end{array}$ & $\mathbf{4 . 5 4}$ & 0.64 & $\mathbf{2 . 4 3}$ & 1.10 \\
$\begin{array}{l}\text { Systematic approach to cycling tourism } \\
\text { development - destination management } \\
\text { with a vision }\end{array}$ & $\mathbf{4 . 5 0}$ & 0.64 & $\mathbf{2 . 6 1}$ & 1.03 \\
$\begin{array}{l}\text { Implementation } \text { of cycling tourism } \\
\text { stakeholders service standardization }\end{array}$ & $\mathbf{4 . 4 6}$ & 0.69 & $\mathbf{2 . 3 9}$ & 1.07 \\
$\begin{array}{l}\text { Connecting the cycling tourism offering } \\
\text { with surrounding destinations }\end{array}$ & $\mathbf{4 . 4 6}$ & 0.69 & $\mathbf{2 . 5 0}$ & 1.23 \\
$\begin{array}{l}\text { Effective cooperation with cycling tourism } \\
\text { stakeholders in the area }\end{array}$ & $\mathbf{4 . 4 6}$ & 0.74 & $\mathbf{2 . 6 1}$ & 1.17 \\
\begin{tabular}{l} 
Overall \\
\hline
\end{tabular} & $\mathbf{4 . 4 3}$ & 0.74 & $\mathbf{2 . 6 4}$ & 1.25 \\
\hline
\end{tabular}

Source: Authors' own construction 
ToSEE - Tourism in Southern and Eastern Europe, Vol. 6, pp. 673-694, 2021.

N. Slavić, T. Ivek: STANDARDIZATION OF SERVICES AS KEY COMPONENTS OF CYCLING ...

In the context of previous efforts made in the region, the ranking of the destination management's vision of cycling tourism development is somewhat surprising. The results indicate that stakeholders do not consider a systematic approach to cycling tourism development more important than promotion, organizing different types of training, incorporating natural and cultural heritage into the cycling tourism offering, or defining seasonal programmes and organizing cycling events. The experts' evaluation suggests the most satisfaction with the educational aspect of destination management.

The overall score of the importance of the cycling tourism offering categories by regional stakeholders demonstrate their strong focus on the role of destination management in regional cycling tourism development, with other categories also having high scores for importance. Although the experts seem to be the most satisfied with the basic elements of cycling tourism development, that is, with the infrastructure, the scores suggest that their level of satisfaction with all attributes of the existing cycling tourism offer is generally low. Also, it is worth noting that the judgement of the experts is more (widely) distributed when expressing satisfaction, and scores for satisfaction are more scattered and substantially lower.

All individual aspects of a destination's cycling tourism supply were also ranked in a single list, according to both their importance, and the satisfaction with the actual situation, in the stakeholders' perspective. The elements were attributed a numerical value, from 1 for the lowest ranked, to 39 for the best ranking (according to the 39 statements in total). The values attributed to the top four elements (in line with the minimum number of elements in a category) in each of the categories were summed in order to evaluate the part-to-whole relationship (Figure 4 and Figure 5).

\section{Figure 3: Part-to-whole relationship of cycling tourism offering categories - experts' ranking of importance}

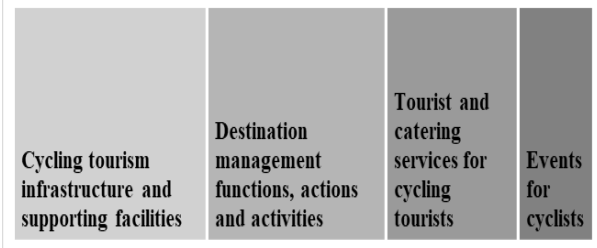

Source: Authors' own construction

\section{Figure 4: Part-to-whole relationship of cycling tourism offer categories - experts' level of satisfaction}

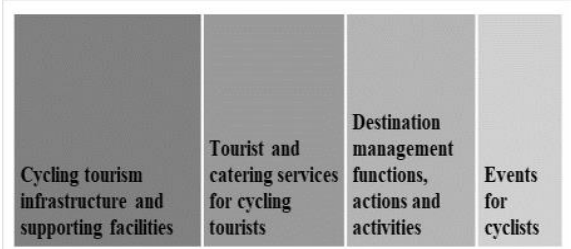

Source: Authors' own construction

The ranking of the top four elements of each cycling tourism offering and the treecharts suggest that "Cycling infrastructure and supporting facilities" is slightly more important than "Destination management functions, actions and activities" to the stakeholders in the region. "Service availability and standardization" is the third most important aspect of the destination's cycling tourism offering, with "Events" being considered the least important. The relationship of the categories is slightly different than in the overall score comparison. The group of experts also demonstrated the highest level of satisfaction with the "Cycling infrastructure and supporting facilities". This category is followed by 
ToSEE - Tourism in Southern and Eastern Europe, Vol. 6, pp. 673-694, 2021.

N. Slavić, T. Ivek: STANDARDIZATION OF SERVICES AS KEY COMPONENTS OF CYCLING ...

"Tourism and catering services for cycling tourists", scoring slightly higher than "Destination management functions, actions and activities". "Events" are (again) ranked the lowest and are considered the least satisfying element of the regional cycling tourism.

\subsection{The model of cycling tourism destination development}

The context of cycling tourism in a destination area is set by regulations, strategic documents that define regional development, and available funding, as well as by stakeholder partnerships and the collaboration of tourism representatives with other sectors (road management companies, associations, government bodies, local residents, public-private alliances, secondary attraction providers, landowners, protected natural area or cultural heritage management, etc.). Table 1 indicates some elements of the cycling tourism offering that could be financed through tenders and operational programmes, but the list is not exhaustive. In line with the objective of this paper, which is to suggest a development scenario of cycling tourism destinations in the form of a model with identified stages, stakeholders, and activities, this section proposes a general and widely applicable cycling tourism development model (Figure 7), which is the result of several logical research stages.

There are several stages that can be identified in the development of a cycling tourism destination. The stages could be disaggregated even further, or some of the activities could possibly be carried out in parallel to speed up the process. The scenario indicates the following key steps of development:

1. the initial stage, that is always focused on creating the infrastructural base for the activity of cycling in the area, for all user groups;

2. improvements to the regional offering, with focus on cycling-specific interests and on designing a product that would be suited for cyclists, while the infrastructure starts to be networked, and more routes are developed, together with greater focus on the service aspect as well as events;

3. regional commitment to cycling tourism is represented by standardizing services, focusing on tourist experiences and specialist knowledge in the area, systematically guided and supported by destination management activities.

Further development implies focusing on the quality of the existing elements of the cycling tourism offering, with a clear vision of further improvements and specialization in the tangible and intangible aspects of the cycling tourists' experience. 
ToSEE - Tourism in Southern and Eastern Europe, Vol. 6, pp. 673-694, 2021.

Figure 5: Conceptual development model of cycling tourism destination area

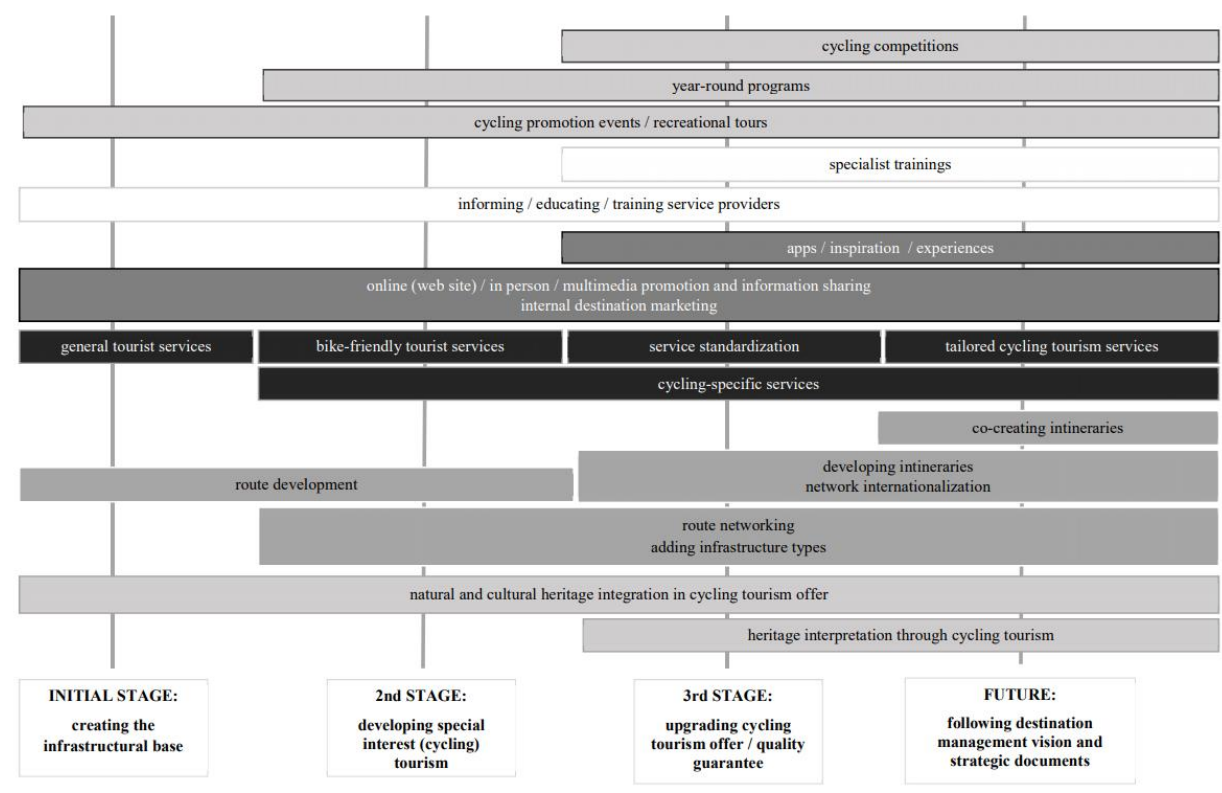

Source: Author contribution

As established in Figures 1 and 2, nature and cultural heritage represent a resource base in accordance to which cycling infrastructure needs to be planned, and cycling tourism developed. The experts' attitudes confirm the importance of resource base integration. When designing the cycling tourism destination product, care should be taken to ensure that heritage is also interpreted as part of the cycling tourism experience in the region. The criteria for heritage interpretive content and services should be included in cycling tourism service standardization regulation.

Infrastructure and amenities are the key of cycling tourism development (Kaya and Erdoğan 2020; Lamont and Buultjens 2011; Pratte 2006). Therefore, creating signposted routes, based on the actual needs of cycling tourists, later networked and also virtually available, is key to regional cycling tourism. As the offering develops, the infrastructure network is supplemented by additional facilities (e.g. equipped rest stops), and wider networking (even cross-border). However, a lot of potential contribution of cross-border tourism routes is still limited in many European borderlands (Stoffelen 2018). Itinerary suggestions enhance the infrastructural element of the offer, and co-creating itineraries via social media and innovative technology is in line with the smart tourism trend.

As for services, in the first development stage the general orientation of service providers in the region is to additionally cater to cyclist needs. In the next stage, service providers are encouraged (educated, subsidized, or have previous positive experience) to adapt their offer to cyclists, although there is no service standardization, and specific service providers (bicycle shops, repair shops) emerge. Based on the destination management's vision and stakeholder collaboration, service standardization is a step towards the niche 
ToSEE - Tourism in Southern and Eastern Europe, Vol. 6, pp. 673-694, 2021.

N. Slavić, T. Ivek: STANDARDIZATION OF SERVICES AS KEY COMPONENTS OF CYCLING ...

market approach and tailored cycling-specific experiences. Service standardization has a multiple role in cycling destination development. Service standardization regulates stakeholder relationships. The focus is on the variety of services (such as in the case of Zagorje, where the Ride\&Bike standardization rulebook (Faculty of Tourism and Hospitality Management 2019) implies criteria for accommodation, catering, nature and cultural attraction sites, as well as some specific service providers in the area). Service standardization is also a destination management tool (in line with achieving the vision), whose implementation needs stakeholder support. Stakeholder involvement should also be supported through some form of incentives (education, financing, equipment). For standardized service providers, standardization is a marketing tool and part of visual identity; it suggests a longer-term level of commitment, and acts as a quality guarantee towards the demand.

The expert's judgement in this research confirmed that promotion activities and different methods of communicating with the cycling tourism market are one of the key aspects of cycling tourism development. Regardless of the form and delivery method (online websites, multi-media contents, GPS logs, tourist fairs, apps, etc.) cycling-specific information needs to be constantly available to potential cyclists in the area. At the same time, destination management needs civil and public sector support and involvement and, therefore, relies on internal marketing and making the stakeholders aware of the cycling tourism potential and potential benefits from standardized services. In addition to information availability, cycling tourism offering should stimulate curiosity about the possible experience in the region (through testimonials and stories).

The stakeholders' judgement and previously analysed practical examples also include stakeholder capacity building through education, workshops, seminars and trainings, which is often overlooked. Upgrading a destination's cycling tourism product (the third stage in the model), requires training in specialist knowledge and know-how that should enable service provider profiling and specific niche orientation. What seems to be missing in the studied case (Table 1) are the events in the region. The experts underlined promotional rides, and the model suggests building upon it, and gradually amplifying the sport/competitive aspect, resulting in a variety of events (according to participant type), represented in a publicly available and constantly upgraded year-round programme. Events could be organized by different actors but destination management should coordinate them towards boosting regional cycling (Soyalp 2018), supporting the use of the existing facilities and contributing to the local community and economy (Buning, Cole and McNamee 2016; Gibson, Kaplanidou and Kang 2012) while even small and medium-sized events have the potential to improve a destination's visibility and image (Oshimi and Harada 2019) in cycling tourism market.

\section{CONCLUSION}

Strategic planning and cooperation across all levels of authority are required to establish a cycling tourism destination, starting with the provision of infrastructure and amenities, based on the actual needs of cycling tourists (Lamont and Buultjens 2011). The destination area is an integral part of service standardization while the outdoor character of cycling implies an inseparable link among service providers, the regional cycling 
ToSEE - Tourism in Southern and Eastern Europe, Vol. 6, pp. 673-694, 2021.

N. Slavić, T. Ivek: STANDARDIZATION OF SERVICES AS KEY COMPONENTS OF CYCLING ...

tourism infrastructure, and other offering elements. The regional service standardization system in Krapina-Zagorje County is found to be similar to a for-profit approach in the market, as far as the number of standards and the quality levels in its Rulebook are concerned. However, the approach follows the logic of regionally implemented service standardization systems that are part of the destination's strategic management and aim to involve a variety of stakeholders into the development of cycling tourism.

This paper has fulfilled its purpose of evaluating the role of service standardization in cycling tourism destination development from the stakeholder perspective. It contributes to filling the research gap in the field of cycling tourism service standardization. Studying a destination area with developed service standards has shown that (from the stakeholder perspective) service standardization aspects (for example, Accommodation facilities affiliated to bike service standardization system; Standardized "bike-friendly" catering facilities; Standardized "bike-friendly" cultural and natural heritage sites along bike routes; Implementation of cycling tourism service standardization system) are all "important" (with scores higher than 4). Even though standardization is (still) not the most important factor in the eyes of stakeholders, the existing standardization criteria enable strategically directing the multi-stakeholder efforts towards achieving the destination's vision. Nevertheless, the experts' evaluation is evidently substantially lower when expressing attitudes with regard to satisfaction, implying the need to improve the existing offering and continue investing funds and efforts into the cycling tourism product.

Research results confirm the findings of previous studies and industry reality, i.e., the importance of infrastructure, information, and services in cycling tourism development, as parts of the system guided and supported by destination management, primarily through promotion, education, integration, and utilizing the available resource base. Regardless of the experts' evaluation in this case, events should not be neglected. Destinations need a synergistic development scenario (such as the conceptual model suggested in this paper), as standardized services are not able to realize their potential benefits if developed in isolation from other offering elements. The inputs gained by secondary and primary sources support the argument that the regional development scenario of cycling tourism needs to be built around standardized services at its core, with service standardization performing multiple functions in cycling destination development, some of the most important being destination branding, benefits to the local economy, and added value and quality guarantee to destination visitors.

\section{REFERENCES}

ADFC (2018), 2018 ADFC-Travelbike Bicycle Travel Analysis, viewed February 8, 2021, https://www.adfc.de/fileadmin/user_upload/Expertenbereich/Touristik_und_Hotellerie/Radreisean alyse/Downloads/ADFC-TravelbikeRadreiseanalyse_2018_Presentation_english_short_version.pdf

- (2017), ADFC Bicycle Travel Analysis (Extended Version), viewed February 8, 2021, https://www.adfc.de/fileadmin/user_upload/Expertenbereich/Touristik_und_Hotellerie/Radreisean alyse/Downloads/170303_Englisch_Langfassung_ADFC_Travelbike_Radreiseanalyse_2017_en. pdf 
ToSEE - Tourism in Southern and Eastern Europe, Vol. 6, pp. 673-694, 2021.

N. Slavić, T. Ivek: STANDARDIZATION OF SERVICES AS KEY COMPONENTS OF CYCLING ...

Adventure Cycling Association n.d., Buiding BIke Tourism: Economic Impact, viewed February 8, 2021, https://www.adventurecycling.org/advocacy/building-bike-tourism/economic-impact/

Allgemeiner Deutscher Fahrrad-Club (2019), 2019 ADFC-Travelbike Bicycle Travel Analysis, viewed January 5 , 2021, https://www.adfc.de/fileadmin/user_upload/Expertenbereich/Touristik_und_Hotellerie/ Radreiseanalyse/Downloads/Datenblatt_Radreiseanalyse2019_en_-_neu.pdf

Bett+Bike ADFC (2021), viewed February 1, 2021, https://www.bettundbike.de/en/bett-bike/bett-bikebetrieb-werden/anmeldeunterlagen/

Buning, R.J., Cole, Z.D. and McNamee, J.B. (2016), "Visitor expenditure within a mountain bike event portfolio: Determinants, outcomes, and variations" Journal of Sport \& Tourism, Vol. 20, No. 2, pp. 103-122, http://dx.doi.org/10.1080/14775085.2016.1239547

CBI (2018), Cycling tourism from Europe, CBI - the Centre for the Promotion of Imports from developing countries, Hague, Netherlands.

Çelik Uğuz, S., İlban, M.O., Özbek, V. and Özyazıcı, G. (2019), Kültür, spor, turizm için bisiklet Burhaniye bisiklet festivali, Detay Publishing, Ankara, Turkey.

Chang, H-W. and Chang, H-L. (2003), "A strategic study of bicycle tourism in Taiwan”, Journal of the Eastern Asia Society for Transportation Studies, Vol. 5, pp. 1675-1685.

Chen, C-F. and Chen, P-C. (2013), "Estimating recreational cyclists' preferences for bicycle routes - Evidence from Taiwan", Transport Policy, Vol. 26, pp. 23-30. https://doi.org/10.1016/j.tranpol.2012.01.001

Cyclists Welcome 2018, Cyclists Welcome, viewed February 1, 2021, https://www.cyclistswelcome.co.uk/

Cykliste vitani n.d., viewed February 2, 2021. https://www.cyklistevitani.cz/Podminky-certifikace/Turistickycil/turisticky-cil-kriteria

Di Giacobe, B., Di Ludovico, D. and D'Ovidio, G. (In Press, Corrected Proof), "Mountain cycle network as enhancer of sustainable economic post-earthquake development in the central Appennines area", Research in Transportation Business \& Management, https://doi.org/10.1016/j.rtbm.2020.100579

European Cyclists' Federation n.d., European Cyclists' Federation: What we do, viewed January 5, 2021, https://ecf.com/what-we-do/cycling-tourism

European Parliament (2009), The European Cycle Route Network EuroVelo: Challenges and opportunities for sustainable tourism, European Parliament, Directorate General for Internal Policies, Policy Department B: Structural and Cohesion policies, Brussels, Belgium.

Europski fondovi 2019, Javni poziv - Program razvoja javne turističke infrastrukture u 2019. godini, viewed April 20, 2021, http://europski-fondovi.eu/content/javni-poziv-program-razvoja-javne-turisti-keinfrastrukture-u-2019-godini

Faculty of Tourism and Hospitality Management (2019), Ride\&Bike pravilnik, Tourism Board of KrapinaZagorje internal documentation

Fahrradportal 2017, "Cycle tourism paves the way for utility cycling”, viewed February 8, 2021, nrvp.de/21014

Gazzola, P., Pavione, E., Grechi, D. and Ossola, P. (2018), "Cycle Tourism as a Driver for the Sustainable Development of Little-Known or Remote Territories: The Experience of the Apennine Regions of Northern Italy", Sustainability, Vol. 10, pp. 1863.

Gibson, H.J., Kaplanidou, K. and Kang, S.J. (2012), "Small-scale event sport tourism: A case study in sustainable tourism", Sport Management Review, Vol. 15, No. 2, pp. 160-170. https://doi.org/10.1016/j.smr.2011.08.013

Giovannini, A., Malucelli, F. and Nonato, M. (2017), “Cycle-tourist network design”, Transportation Research Procedia, Vol. 22, pp. 154-163. https://doi.org/10.1016/j.trpro.2017.03.022

Institute for Transport Studies University of Natural Resources and Life Sciences (2019), Guidelines for sustainable bicycle tourism: Deliverable 3.3.1 (WP3 Ecotourism planning), Institute for Transport Studies University of Natural Resources and Life Sciences, Vienna, Austria. Viewed January 8, 2021. http://www.interreg-danube.eu/uploads/media/approved_project_output/0001/36/ cfb8514ba973699218d4caf1fb4ec0371766d5d9.pdf

Istra Bike n.d., viewed March 5, 2021. http://www.istria-bike.com/en/accomodation/project-info

Juneja, P. (n.d.), MSG Management Study Guide, viewed January 25, 2021, https://www.managementstudyguide.com/survey_method.htm

Kaya, I. and Erdoğan, G.Ö. (2020), "The economic contribution of cycling festivals on tourism sector: A study on cycling festivals in Turkey", Focus on Research in Contemporary Economics (FORCE), Vol.1, No. 2, pp. 103-118. https://www.forcejournal.org/index.php/force/article/view/16

Krieger, C. 2007, Touristische Projekte: Cycling Tourists - Who they are, what they want, and how they improve regional economy?, vieved 22 April, 2021, nationaler-radverkehrsplan.de

Lamont, M. (2009), "Reinventing the Wheel: A Definitional Discussion of Bicycle Tourism", Journal of Sport \& Tourism, pp. 5-23.

Lamont, M. (2014), “Cycling \& Tourism", Tourism Review International, Vol. 18, No. 1, editorial. 
ToSEE - Tourism in Southern and Eastern Europe, Vol. 6, pp. 673-694, 2021.

N. Slavić, T. Ivek: STANDARDIZATION OF SERVICES AS KEY COMPONENTS OF CYCLING ...

Lamont, M. and Buultjens, J. (2011), "Putting the brakes on: impediments to the development of independent cycle tourism in Australia", Current Issues in Tourism, Vol. 14, No. 1, pp. 57-78. https://doi.org/10.1080/13683500903250799

Lamont, M, and Jenkins, J. (2013), "Segmentation of Cycling Event Participants: A Two-Step Cluster Method Utilizing Recreation Specialization", Event Management, Vol. 17, No. 4, pp. 391-407. https://doi.org/10.3727/152599513X13769392444666

Lőrincz, K., Banász, Z. and Csapó, J. (2020), "Customer Involvement in Sustainable Tourism Planning at Lake Balaton, Hungary-Analysis of the Consumer Preferences of the Active Cycling Tourists", Sustainability, Vol. 12, No. 12, pp. 5174. https://doi.org/10.3390/su12125174

Marcussen, C.H. (2009), Cycling tourism in north-western Poland, on Bornholm and in southern Sweden, Centre for Regional and Tourism Research, Bornholm, Denmark.

Marušić, M., Prebežac, D. and Mikulić, J. (2019), Istraživanje turističkih tržišta, Sveučilište u Zagrebu Ekonomski fakultet, Zagreb, Croatia.

Međimurje Bike n.d., viewed March 2, 2021. https://www.medimurje-bike.com/cyclist-welcome

Ministarstvo turizma i sporta 2021, Javni poziv za podnošenje zahtjeva za dodjelu bespovratnih sredstava temeljem Programa razvoja cikloturizma na kontinentu u 2021. godini, viewed April 20, 2021, https://mint.gov.hr/vijesti/javni-poziv-za-podnosenje-zahtjeva-za-dodjelu-bespovratnih-sredstavatemeljem-programa-razvoja-cikloturizma-na-kontinentu-u-2021-godini/22306

Ministarstvo turizma Republike Hrvatske (2016), Pravilnik o razvrstavanju, kategorizaciji $i$ posebnim standardima ugostiteljskih objekata iz skupine Hoteli, Narodne novine 56/2016.

Mintel 2009. Cycling Holidays - International. Mintel Ltd.

MountainBikeHolidays 2021, viewed January 5, 2021, https://www.bike-holidays.com/en/bike-hotels/bikeservices-hotels/

— 2021, viewed January 5, 2021, https://www.bike-holidays.com/en/bike-hotels/certified-quality/

Oshimi, D. and Harada, M. (2019), "Host residents' role in sporting events: The city image perspective", Sport Management Review, Vol. 22, No. 2, pp. 263-275. https://doi.org/10.1016/j.smr.2018.04.002.

Patton, M.Q. (2018), "Expert sampling” in Frey, B. (Ed.), The SAGE encyclopedia of educational research, measurement, and evaluation, SAGE Publications Inc., pp. 648-649. https://www.doi.org/10.4135/9781506326139.n251

Piket, P., Eijgelaar, E. and Peeters, P. (2013), "European cycle tourism: a tool for sustainable regional rural development", Applied Studies in Agribusiness and Commerce, Vol. 7, No. 2-3, pp. 115-119. https://doi.org/10.19041/APSTRACT/2013/2-3/19

Pratte, J. (2006), "Bicycle tourism: on the trail to economic development", Prairie Perspectives: Gegraphical Essays, Vol. 9, No. 1, pp. 62-84.

Preez, M.D. and Lee, D.E. (2016), "The economic value of the Trans Baviaans mountain biking event in the Baviaanskloof Mega-Reserve, Eastern Cape, South Africa: A travel cost analysis using count data models", Journal of Outdoor Recreation and Tourism, Vol. 15, pp. 47-54. https://doi.org/10.1016/j.jort.2016.07.003

Queensland Government Statistician's Office 2019, Collecting Dana, viewed January 21, 2021, https://www.qgso.qld.gov.au/about-statistics/collecting-data/survey-methods

RAM DC d.o.o. Čakovec for Zagreb County tourism board (2017), PRAVILNIK STANDARDA KVALITETE CYCLIST WELCOME QUALITY I DJELOVANJU CW MREŽE U ZAGREBAČKOJ ŽUPANIJI, Zagreb, http://www.visitzagrebcounty.hr/wordpress/wp-content/uploads/2018/10/CWQ-pravilnikZ\% $5 \%$ BD.pdf

Ride\&Bike: Ride\&Bike info 2021, viewed April 15, 2021. https://rideandbike.eu/info/

Ritchie, B. W, Tkaczynski, A. and Faulks, P. (2010), "Understanding the motivation and travel behaviour of cycle tourists using involvement profiles", Journal of Travel \& Tourism Marketing, Vol. 27, pp. 409-425. https://doi.org/10.1080/10548408.2010.481582

RoadbikeHolidays 2021, viewed January 5, 2021. https://www.roadbike-holidays.com/en/

— 2021, viewed January 5, 2021. https://www.roadbike-holidays.com/en/hotels/bike-plus/

Rotar, J. (Ed.) (2012), Kako razvijati kolesarski turizem? RRA Koroška, Maribor, Slovenia. http://www.bicy.it/docs/35/Kako_razvijati_kolesarski_turizem.pdf

Skupnost občin Slovenije: Priročnik za razvoj kolesarskih destinacij 2016, viewed February 5, 2021, https://skupnostobcin.si/wp-content/uploads/2016/06/5.pdf

Zagorje Bike, n.d., viewed 5 April, 2021, https://www.zagorjebike.com.hr/wp-content/uploads/2021/05/ RIDEBIKE-pravilnik-s-prilozima-FINAL.pdf

Soyalp, L. (2018), "Bicycle tourism in Ostrobothnia / Finland - Potential and Challenges", viewed January 21, 2021 ,

https://www.researchgate.net/profile/Levent_Soyalp/publication/343135496_BICYCLE_TOURISM _IN_OSTROBOTHNIA_FINLAND_- 
ToSEE - Tourism in Southern and Eastern Europe, Vol. 6, pp. 673-694, 2021.

N. Slavić, T. Ivek: STANDARDIZATION OF SERVICES AS KEY COMPONENTS OF CYCLING ...

Potentials_and_Challenges/links/5f1fd3cea6fdcc9626b9eebc/BICYCLE-TOURISM-IN-

OSTROBOTHNIA-FINLAND-Potentials-and-Challenges.pdf

Stoffelen, A. (2018), "Tourism trails as tools for cross-border integration: A best practice case study of the Vennbahn cycling route", Annals of Tourism Research, Vol. 73, pp. 91-102.

Sustrans (1999), Cycle Tourism, Sustrans, Bristol, UK.

The Croatian Bureau of Statistics 2011, The Croatian Bureau of Statistics: Census of Population, Households and Dwellings 2011, viewed April 21, 2021. https://www.dzs.hr/Hrv_Eng/publication/2012/SI1469.pdf

The Outdoor Industry Association 2018, The Outdoor Recreation Economy, vieved 5 April 2021, https://outdoorindustry.org/advocacy/

The Path Less Peddaled 2013, What is bicycle tourism?, viewed February 8, 2021, https://www.pathlesspedaled.com/2013/02/17/what-is-bicycle-tourism/

Tourist Board of Krapina - Zagorje county 2021, VisitZagorje: Explore Zagorje, viewed April 5, 2021, https://visitzagorje.hr/en/

Turistička zajednica Splitsko-dalmatinske županije; Biciklistički savez Splitsko-dalmatinske županije; Splitskodalmatinska županija (2015), STANDARDI I PRAVILNICI ZA USKLAĐENI RAZVOJ CIKLOTURIZMA U SPLITSKO-DALMATINSKOJ ŽUPANIJI, Split, https://www.dalmatia.hr/hr/ priopcenja/standardi-i-pravilnici-za-uskladeni-razvoj-cikloturizma-u-splitsko-dalmatinskoj-zupaniji-3

Weed, M., Bull, C., Brown, M., et al. (2014), “A systematic review and meta-analyses of the potential local economic impact of tourism and leisure cycling and the development of an evidence-based market segmentation", Tourism Review Intenational, Vol. 18, pp. 37-55. https://doi.org/10.3727/154427214X13990420684482

Weston, R, Davies, N., Peeters, P., Eijgelaar, E. and Lumsdon L. (2012), The European Cycle Route Network EuroVelo: Challenges and Opportunities for Sustainable Tourism (update of the 2009 study). European Parliament, Directorate General for Internal Policies, Policy Department B: Structural and Cohesion Policies, Transport and Tourism, Brussels, Belgium.

Zagorje Bike n.d., viewed February 2, 2021, https://www.zagorjebike.com.hr/en/about-the-project/

Zagorje Bike 2021, Zagorje Bike: Experience Zagorje in a special way, viewed April 22, 2021, https://www.zagorjebike.com.hr/en/

Združenje za pohodništvo in kolesarjenje giz (2018), POSLOVNIK O IZVEDBI SPECIALIZACIJE NASTANITEV ZA POHODNIKE IN KOLESARJE ter ČLANSTVU SPECIALIZIRANIH NAMESTITEV IN DESTINACIJ V ZDRUŽENJU POHODNIŠTVO \& KOLESARJENJE giz, Združenje pohodništvo in kolesarjenje giz, Ljubljana, Slovenia, https://slovenia-outdoor.com/wpcontent/uploads/2019/11/Poslovnik-o-izvedbi-specializacije-nastanitev.pdf

Združenje za pohodništvo in kolesarjenje giz 2017 POZIV K ODDAJI PRIJAV ZA PRIDOBITEV ZNAKA KOLESARSKEGA HOTELA OZ. DRUGEGA NASTANITVENEGA OBRATA, viewed 5April 2021, https://www.slovenia.info/uploads/dokumenti/razpisi/special-razpis2017-kolo.xlsx

Nataša Slavić, $\mathrm{PhD}$, Assistant professor

University of Rijeka, Faculty of Tourism and Hospitality Management

Primorska 46, Ika, Opatija, Croatia

+38551294697

natasa.slavic@fthm.hr

Tanja Ivek, MA, Senior advisor

Zagorska razvojna agencija

Frana Galovića 1b, Krapina, Croatia

+ 38549373161

tanja@zara.hr 